\title{
The effect of business regulation on social progress
}

\author{
Kenza Ghazaouni $^{\mathbf{a}^{*}}$ and Okechukwu Lawrence Emeagwali ${ }^{\mathrm{a}}$
}

\begin{tabular}{l}
${ }^{a}$ Girne american University, Cyprus \\
\hline C H R O N I C L E \\
\hline Article history: \\
Received: September 9, 2020 \\
Received in revised format: Sep- \\
tember 9, 2020 \\
Accepted: November 3, 2020 \\
Available online: November 3, \\
2020 \\
\hline Keywords: \\
Business regulation \\
Social progress \\
Ease of doing business \\
Social progress index (SPI) \\
Foundations of wellbeing \\
Personal freedom and choice \\
Inclusiveness
\end{tabular}

\section{Introduction}

People's quality of life and overall well-being indicates a nation's welfare compared to the commonly used economic measures such as the Gross Domestic Product (GDP). However, GDP has a significant influence on people's living standards due to its direct impact on government spending on the development of social amenities and other public resources. The measure of a country's economic growth correlates with social progress and influences the political, legal, and social institutions with more organized countries growing faster (Messaoud \& Teheni, 2014, p. 69). Business organizations ultimately influence economic growth, hence a crucial determinant of social progress. Businesses stimulate economic growth and development and contribute to poverty alleviation through income distribution. Profit-seeking ventures engage other organizations and individuals to outsource resources during manufacturing, distribution, and sales at a cost or a profit margin generating incomes. While businesses remain crucial to a nation's economy, they remain highly dependent on the regulatory environment. According to the World Bank (2013) business, regulation has a significant influence on the economic outcomes at the micro and macro levels (p.30). Trade, productivity, employment, financial access, and informal sectors' success enhance social * Corresponding author. Tel.: +905338849428

E-mail address: kenza.ghazaouni@gmail.com (K. Ghazaouni)

(C) 2021 by the authors; licensee Growing Science, Canada. doi: $10.5267 /$ j.ijdns.2020.11.002 O 2021 by the authors; licensee Growing Science, Canada.

\begin{abstract}
This study sought to determine the effect of business regulation on social progress. The dependent variable, social progress, was measured in terms of social progress index of the sampled countries. On the other hand, the independent variable, business regulation, was measured in terms of busiover a period of five years (2014-2018). In order to determine the appropriate model for analysis, the study conducted the Hausman test where it was established that the random effect model was multiple regression analysis of the random effect model, the study findings indicated that business regulation has a positive and significant effect on social progress as given across all the six models that were estimated in this study. However, the overall effect of regulation, as given by the estian addition business regulation significantly affects social progress. Further, the findings implied that, governments should devote additional resources towards addressing the social indicators of progress to meaningfully improve the living standards of residents, instead of solely focusing on economic countries according to their levels of development, it recommends for further research to determine the effect of business regulation on social progress in low-income, middle-income, and highincome countries to allow for comparison of findings from countries that are at different levels of A B S T R A C T
\end{abstract}


progress subject to regulation. Business regulation benefits or burdens organizations influencing performance and induces a dynamic force that enables or constraints organizational performance. Regulation influences labor productivity, innovation, and corporate investment in a region, and the total factor productivity (Messaoud \& Teheni, 2014, p. 71). Human wellbeing and the quality of life are thereby dependent on the adoption of suitable regulatory policies to enhance people's quality of life. Social progress is a modern approach for analyzing a nation's prosperity encompassing human wellbeing and environmental attributes to supplement the deficiencies of GDP. In 2008, the French President Sarkozy approved and tasked a commission chaired by Joseph Stiglitz to measure social progress and economic performance, highlighting the impracticality of GDP (Almatarneh \& Emeagwali, 2019, p. 1037). The Social Progress Imperative report in 2015 acknowledges a relationship between a nation's SPI score and the GDP. Worth noting is the significant difference between economic growth and social progress. While the report suggests an economic growth that increases the average annual income from $\$ 14 \mathrm{k}$ to $\$ 23 \mathrm{k}$, social development only increases by $2.3 \%$ by 2030 (Social Progress Imperative, 2015, p. 11). Nations with high social progress such as New Zealand and Norway register SPI scores of approximately 87 with other major economies, for instance, Germany registering scores above 77. The world's SPI score estimated at 62.4 in 2030 remains significantly low, and the slow rate of growth requires improved socioeconomic policies that promote people's wellbeing and environmental preservation.

\section{Literature Review}

\subsection{Social progress}

Social progress relies on the ability and capacity of a nation to satisfy the citizens' basic needs while promoting the apparent building blocks that help individuals enhance their quality of life and attain full potential. Social Progress Index (SPI), developed by the Social Progress Imperative, indicates the extent nations provide for the needs of the citizens. SPI examines components of fundamental human needs to available opportunities, for instance, in higher education and politics (Social Progress Imperative, 2015, p. 7). According to the Social Progress report in 2015, the traditional measure of a country's prosperity through GDP is skewed and fails to consider crucial attributes like equity and people's wellbeing. The Social Progress Imperative, therefore, constructed the index to focus on the citizens' priorities rather than the monetary characteristics depicted by the GDP (Almatarneh \& Emeagwali, 2019, p. 1037). Politicians and governments have, in the past, advocated for comprehensive assessments that focus on overall citizen's wellbeing rather than deploying the traditional measures of economic performance.

\subsection{Measurement of Social Progress}

Measuring social progress is crucial to determine the actual impact of a country's economic growth on its citizens. Previously, multiple studies have adopted other measures of social progress other indicators to examine social development (Bečić et al., 2012, p. 458). The Social Progress Index, therefore, is not the first framework developed to measure a nation's development with other measures such as the "Human Development Index, National Wellbeing Index, and the National Welfare Index" (Almatarneh \& Emeagwali, 2019, p. 1039). The SPI is, however, the most recent tool for measuring a nation's progress beyond the GDP analyzing basic human needs, the foundation of wellbeing, and opportunities. Almatarneh and Emeagwali highlight the unique attributes of SPI compared to other methods since SPI measures the input rather than the output. The SPI utilizes actionable measurement units, while other development measures use proxies (p. 1039).

The three main dimensions of the SPI are further subdivided into 12 components (as illustrated in table 1) used to determine the weight of each progress indicator. Bruno and Faggini (2017) hypothesize that policymakers should focus on both economic performance and overall citizen's wellbeing. Bruno and Faggini, therefore, test the effects of politicians adopting multidimensional perspectives towards educational expenditure. Research findings indicate that welfare, quality of life, environment, and people's wellbeing should be the critical concerns for policymakers since economic performance is skewed and unreliable. Ultimately, the decision maker's perceptions will influence their decision-making, affecting social progress.

Table 1

Social Progress Index component-level framework

\begin{tabular}{|c|c|c|}
\hline Basic Human Needs & Foundation of wellbeing & Opportunity \\
\hline $\begin{array}{ll}\text { - } & \text { Nutrition and basic medical health } \\
\text { - } & \text { Water and sanitation } \\
\text { - } & \text { Shelter } \\
\text { Personal safety }\end{array}$ & $\begin{array}{l}\text { - } \\
\text { - } \\
\text { Access to basic knowledge } \\
\text { cation } \\
\text { - } \quad \text { Health and wellness } \\
\text { - Environmental quality }\end{array}$ & $\begin{array}{ll} & \text { Personal right } \\
\text { - } & \text { Personal freedom } \\
\text { - } & \text { Inclusiveness } \\
\text { - } & \text { Access to advanced education }\end{array}$ \\
\hline
\end{tabular}

\subsection{GDP vs SPI vs Economic Growth}

Businesses play a crucial role in economic growth and development by creating employment and facilitating income distribution, enabling citizens to improve their quality of life individually, leading to social progress. However, businesses cannot single-handedly influence GDP and social development and rely on other sectors for necessary cultural shifts, social innovation, and collaboration across dependent sectors. The government remains at the core of social progress and global developmental goals through its legitimacy to enact new policies and solutions. Civil society and businesses also need to play a role per industry rules and regulations. Companies already play a role in promoting social progress through supporting health 
provision, education, and infrastructural development. For instance, in India, the private sector accounts for $58 \%$ of all enrollments in tertiary institutions (Social Progress Imperative, 2015, p. 6).

Although an increase in GDP does not lead to an equal improvement in social progress, increased GDP per capita influences components of social development. According to the Social Progress Imperative report (2015), the association between income and social growth varies across groups and depending on the specific components (p. 13). The Imperative conducted a simulated experiment to predict and examine SPI as a complementary system to analyze social progress. A $10 \%$ increase in GDP per capita, for instance, had a 2.02 unit increase on access to tertiary education in areas of high social development and 0.55 in low social progress areas.

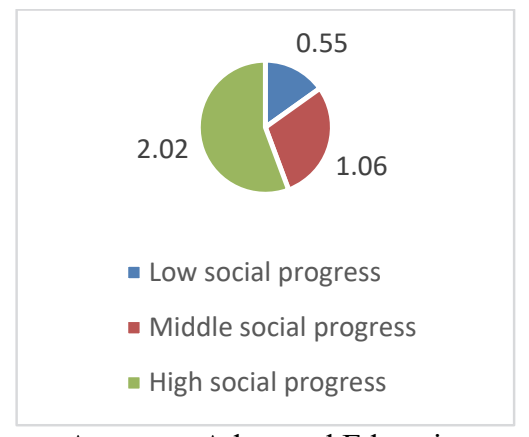

Access to Advanced Education

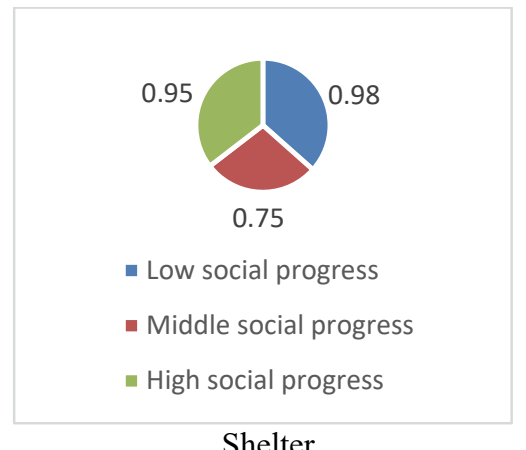

Shelter

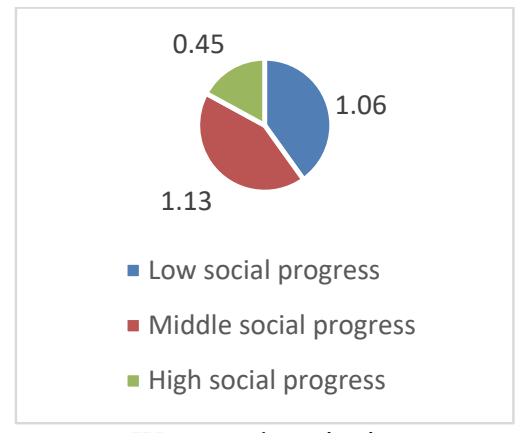

Water and Sanitation

Fig. 2. 10\% increase in GDP per capita across different groups (Social Progress Imperative, 2015, p. 13).

Conversely, a 10\% increase in GDP per capita had higher estimated unit changes for water and sanitation among middle and low social progress regions. The variations highlight the difference in spending with high social progress areas focusing on tertiary needs. In contrast, people in the low and middle-income areas spend on necessities (Social Progress Imperative, 2015, p. 13). Businesses facilitate income distribution through employment, taxes, profit margins, and distribution costs, which influence the GDP by drawing foreign investors, consequently raising the GDP per capita. Deloitte UK and the Social Progress Imperative conducted a study to examine the impact of Foreign Direct Investment (FDI) on social progress using data from the 2015 SPI report. The report utilized data from 132 countries throughout the world and adopted FDI metrics to estimate the apparent influence on inclusive social growth. FDI increases business investments in health, education, creates employment opportunities and improves people's incomes (Deloitte \& Social Progress Imperative, 2015, p. 4). Improving an individual's socioeconomic status enhances the quality of life and overall wellbeing, enhancing social progress.

\subsection{Business Regulation}

Business operations are subject to some form of regulation at various stages and levels during development, which is often enacted through government policies. The theory of institutional law creates additional principle responsibilities inducing accountability, independence, and regulator transparency. Sumkoski (2016) researched to examine the socioeconomic perspective of business regulation utilizing data from Bangladesh and OECD countries. The author hypothesizes the focus of economic and political attributes of regulation often neglects essential social factors, norms, and informal ventures. Sumkoski, through his work, compares social capital to the informal institutions citing "social capital can be modeled as a deep determinant of economic development" (Sumkoski, 2016, p. 4). Hence, businesses promote social progress through enhancing social capital, based on policy guidelines and regulations.

\subsubsection{Types of business regulation}

World Bank conducted a study in 2013 to determine the effects of business regulations analyzing various theoretical mechanisms on how the law affects economic growth. The most common theoretical perspective regarding regulation examines the labor regulations and the cost of firm entry to a nation's markets. Often, rules and regulations are associated with increasing the cost of entry, causing business ventures to remain in the informal economy. Bruhn $(2011,2013)$ conducts natural experiments utilizing the Mexican government data on employment between 2000 and 2004 to determine the significance of business registration reforms. The author reports that business registration reforms increased the number of registered ventures by $5 \%$ and employment by $2 \%$ while reducing profitability by $3 \%$ due to high competition. The increase in registered business ventures originated from former employees' tendency to start businesses rather than registering informal investments. International Finance Corporation (IFC) conducted a study in 2013 to determine the contribution of the private sector towards job creation and poverty alleviation. IFC did the research to identify the factors that inhibit economic growth, investments, financial access, infrastructure, and educational skill sets. IFC reported the private sector as the biggest driver of employment creating opportunities to increase productivity, boosting living standards, and improves social cohesion. According to the researchers, increasing available opportunities through relaxed firm entry regulation increases people's incomes, enabling 
them to access basic needs above the poverty level (IFC, 2013, p. 4). A reform on market entry regulation thereby influences businesses and consequently job opportunities that facilitate interaction within the labor market. The interaction creates a sense of belonging, enhances people's social identity, improves self-esteem, satisfaction promoting social progress.

Businesses aim to maximize profits in all their market environments subject to trade regulations and costs. According to the World Bank (2013), businesses remain concerned about enhancing their competitiveness in the global market, but organizations still incur high trade costs through logistics and regulations. Big business operational costs limit profit margins preventing organizations from utilizing their full production capabilities, consequently inhibiting competitiveness. Hoekman and Nicita (2011) conducted a cross-sectional study using data from 105 national economies in 2006 to examine the significance of logistics and the tariff and nontariff costs on trade. The research findings indicated that high import and export costs due to regulation adversely affected trade volumes. Similarly, tax regulations influence business operations affecting economic growth, a significant determinant of poverty reduction, and economic development. Divanbeigi and Ramalho (2015) conducted a study to examine the link between regulation, firm entry, and growth adopting the Doing Business indicators developed by the World Bank. The researchers measured the strength of the laws and efficiency during different stages of a business life cycle. Research findings indicate a complicated relationship between GDP per capita and the factors capable of affecting businesses. Although the small changes in regulations have negligible impacts on growth, a shift from the lowest quartile towards the highest quartile significantly increases the annual GDP per capita (p. 10).

Regulations on credit markets, and investor rights and protection also influence social progress through their economic growth and the overall quality of life. Credit markets affect the amount of money circulating in the economy, while credit reporting systems ensure information symmetry within the financial market. Giannetti and Jentzsch (2013) conducted a study to analyze credit-reporting policies, financial identification, and intermediation. The researchers utilized data from 172 countries collected between 2000 and 2008, adopting a more sophisticated method other than the standard panel data for analysis. Giannetti and Jentzsch selected a synthetic control group comprising of similar countries with no credit market reforms. The research findings indicate compulsory credit reporting enhances financial accessibility and intermediation primarily when used alongside other information systems. Investor rights and protections, especially those enabling organizations to solve their issues, immediately influence business creation and operations. Favorable investor rights and protections attract investors, optimize business operations, and allow ventures to recover upon insolvency (World Bank, 2013, p. 37). Gine and Love (2009) conducted a study to examine the efficiency of bankruptcy reforms in Colombia. The researchers utilized data on firms that filed for bankruptcy between 1996 and 2003, analyzing how the 1999 law reforms affected recovery rates. Research findings indicate that the change improved recovery rates of viable business organizations after comparing the duration of reorganization and liquidation before and after the reform. The research suggests a positive association between improved regulations and economic performance, increasing economic and social development in a nation.

\section{Empirical Methodology and Data}

\subsection{Data}

This study sought to determine the effect of business regulation on social progress using a sample of 248 countries. Consequently, the study will use secondary data, and in particular, panel data from 248 countries. The dependent variable is social progress which will be measured in terms of the social progress index of the sampled countries. On the other hand, the independent variable of the study is business regulation which will be measure in terms of the business regulation score. Control variables of the study are; basic human needs, personal wellbeing, availability of opportunities, nutrition, and safety. Data on social progress will be obtained from the Social Progress Imperative while that on business regulation and the control variables will be obtained from the World Bank's Governance Indicators, and World Development Indicators respectively. The scope of this study will be over a period of five years (2014-2018), including the year 2018 .

Table 2

Variables and measurement of variables

\begin{tabular}{lll}
\hline Type of the variable & Measurement & Source \\
\hline $\begin{array}{l}\text { Independent variable: } \\
\text { Business regulation }\end{array}$ & Business regulation score & World Bank- Governance indicators \\
$\begin{array}{l}\text { Dependent variable: } \\
\text { Social progress }\end{array}$ & Social progress index & Social Progress Imperative \\
Control variables: & & \\
Basic human needs & Proportion of the population & World Bank's WDI \\
Wellbeing & Personal wellbeing score & World Bank's WDI \\
Opportunity & Access to opportunity score & World Bank's WDI \\
Nutrition & Access to nutrition score & World Bank's WDI \\
Safety & Safety index & \\
\hline
\end{tabular}

\subsection{Methodology}

In order to empirically estimate the relationship between social progress, business regulation and the five control variables that were considered in this study, the study adopted a regression analysis model that was presented as; 
where Social Progress Index is the social progress of the $i^{\text {th }}$ country at time $t$ and is the dependent variable of the study. Regulation is the business regulation index for sampled countries, Basic are the basic human needs, Wellbeing are the foundations of wellbeing, Opportunity is the availability of opportunities, Nutrition is the nutrition and basic medical care, and Safety is personal safety. On the other hand, $\beta_{i \prime s}$ are the regression coefficients to be estimated in the regression model while $\varepsilon_{i t}$ is the error term of regression which in this case captures all other factors that affect Social progress, but are not included in the model as given in Eq. (1). Furthermore, a principal component analysis (PCA) was conducted in order to determine the shared variation of the various indicators of business regulation representing the level of regulation. Results of the analysis are as presented in Fig. 3.

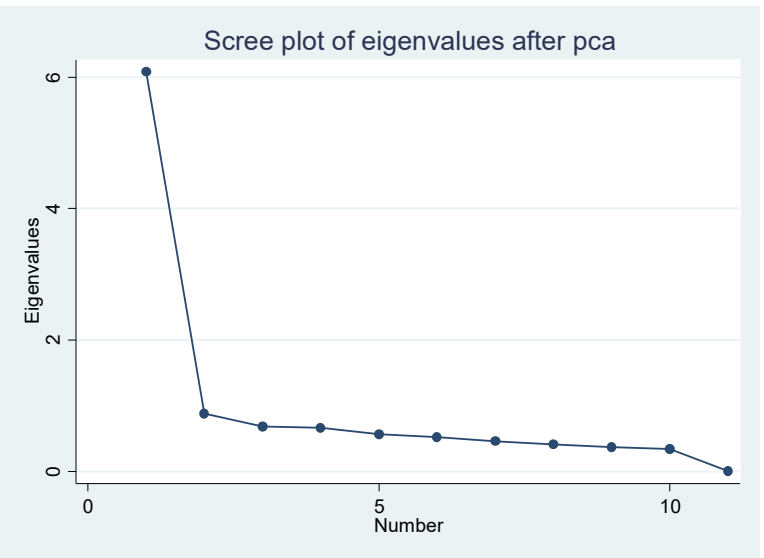

Fig. 3. Screen plot of eigen values

According to this figure, only the first component has eigenvalue that is above 1. Based on the result, the study used obtained first component in subsequent analysis. The corresponding eigenvalues of the correlation matrix and the factor pattern of the first component are as presented in Table 3 and Table 4.

Table 3

Eigenvalues of the correlation matrix

\begin{tabular}{|c|c|c|c|c|}
\hline Component & Eigenvalue & Difference & Proportion & Cumulative \\
\hline Comp1 & 6.08062 & 5.20251 & 0.5528 & 0.5528 \\
\hline Comp2 & 0.87811 & 0.19305 & 0.0798 & 0.6326 \\
\hline Comp3 & 0.68506 & 0.02211 & 0.0623 & 0.6949 \\
\hline Comp4 & 0.66295 & 0.09627 & 0.0603 & 0.7552 \\
\hline Comp5 & 0.56667 & 0.0419 & 0.0515 & 0.8067 \\
\hline Comp6 & 0.52478 & 0.06166 & 0.0477 & 0.8544 \\
\hline Comp7 & 0.46312 & 0.04979 & 0.0421 & 0.8965 \\
\hline Comp8 & 0.41333 & 0.0426 & 0.0376 & 0.9341 \\
\hline Comp9 & 0.37073 & 0.02538 & 0.0337 & 0.9678 \\
\hline Comp10 & 0.34535 & 0.33606 & 0.0314 & 0.9992 \\
\hline Comp11 & 0.00929 & 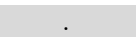 & 0.0008 & 1.0000 \\
\hline
\end{tabular}

Table 4

Factor pattern of the first component

\begin{tabular}{|c|c|c|c|}
\hline Variable & Comp1 & Variable & Comp1 \\
\hline Doing business & 0.4035 & Protecting minority investors DB06 & 0.2982 \\
\hline Starting a business & 0.2793 & Paying taxes & 0.2822 \\
\hline Dealing with construction permits & 0.2719 & Trading across borders & 0.3047 \\
\hline Getting electricity & 0.3077 & Enforcing contracts & 0.2805 \\
\hline Getting credit & 0.2776 & Resolving insolvency & 0.3109 \\
\hline Protecting minority investors DB15 & 0.2769 & & \\
\hline
\end{tabular}

\subsection{Empirical Results}

This section presents empirical findings on the effect of business regulation on social progress. More particularly, it presents both the descriptive and empirical analysis results. 
Descriptive statistics

Correlation analysis

Correlation analysis was conducted to determine the correlation between business regulation and social progress, and the six control variables under investigation. Results of regression analysis are as presented in Table 5.

Table 5

Descriptive statistics

\begin{tabular}{|c|c|c|c|c|c|c|c|c|}
\hline Variables & 1 & 2 & 3 & 4 & 5 & 6 & 7 & 8 \\
\hline 1. Social progress & 1 & & & & & & & \\
\hline 2. Basic needs & $0.953 * * *$ & 1 & & & & & & \\
\hline 3. Wellbeing & $0.983 * * *$ & $0.932 * * *$ & 1 & & & & & \\
\hline 4. Opportunity & $0.916 * * *$ & $0.817 * * *$ & $0.866^{* * *}$ & 1 & & & & \\
\hline 5. Nutrition & $0.916 * * *$ & $0.961 * * *$ & $0.902 * * *$ & $0.750 * * *$ & 1 & & & \\
\hline 6. Safety & $0.762 * * *$ & $0.723 * * *$ & $0.706^{* * *}$ & $0.782 * * *$ & $0.624 * * *$ & 1 & & \\
\hline 7. Information & $0.933 * * *$ & $0.899 * * *$ & $0.938 * * *$ & $0.870 * * *$ & $0.862 * * *$ & $0.667 * * *$ & 1 & \\
\hline 8. Regulation & $0.842 * * *$ & $0.813 * * *$ & $0.828 * * *$ & $0.786 * * *$ & $0.768 * * *$ & $0.673 * * *$ & $0.833 * * *$ & 1 \\
\hline
\end{tabular}

As it can be shown from the correlation matrix presented in Table 4, there is a strong and significant correlation between Business Regulation and Social Progress $(\mathrm{r}=0.842)$. The findings also indicate that there is a strong and significant correlation between the control variables and Social Progress; Basic need and Social Progress $(r=0.953)$, Wellbeing and Social Progress $(\mathrm{r}=0.983)$, Opportunity and Social Progress $(\mathrm{r}=0.916)$, Nutrition and Social Progress $(\mathrm{r}=0.916)$, Safety and Social Progress $(\mathrm{r}=0.762)$, and Information and Social Progress $(\mathrm{r}=0.933)$.

\section{Hausman test}

$\mathrm{H}_{0}$ : Random effect model is more appropriate

$\mathrm{H}_{\mathrm{A}}$ : Fixed effect model is more appropriate

The Hausman test was used to select the appropriate model between the fixed and random effect models for analysis. Results of the test statistic are presented as shown in Table 5.

Table 6

Hausman test to determine the appropriate model

\begin{tabular}{lll}
\hline Test: & Ho: & difference in coefficients not systematic \\
& chi2 $2(10)=(b-B)^{\prime}\left[\left(V_{-}-V_{-}\right)^{\wedge}(-1)\right](b-B)$ \\
& 2.81 \\
& Prob $>$ chi2 $=0.9856$ \\
& $\left(\mathrm{~V} \_\right.$b-V_B is not positive definite $)$ \\
\hline
\end{tabular}

Test results of the Hausman test to determine the appropriate model between the fixed effect and random effect models, as presented in Table 3, indicate that the test statistic $\left(\chi^{2}(10)=2.81, p>.05\right)$ is not statistically significant at the $5 \%$ level of significance. Therefore, the decision is that we do not reject the null hypothesis of the random effect being the most appropriate model. Consequently, we prefer the random effects model over the fixed effect.

\section{Regression Analysis}

In order to determine the effect of business regulation on social progress, this study used the regression analysis technique to estimate the coefficients of the independent variable (Business Regulation) and the control variables (Basic needs, Wellbeing, Opportunity, Nutrition, and Safety) and their significance in predicting Social Progress. With the Hausman test having shown that the random effect model was more appropriate, the study estimated the effect of business regulation on social progress using the random effect model. The regression coefficients of the independent and control variables under the six different models that were analyzed in this study are summarized as shown in Table 7. Regression results presented in Table 6 indicate that there were 782 observations that were included in each of the six models that were estimated in this study. This therefore is an indication that the data was balanced. The first model is the baseline model which shows the effect of Business regulation on Social progress without the influence of the control variables. According to the tabulated result, there is a positive and statistically significant effect of Business regulation on Social progress $(\beta=0.683, p<.05)$. The second model shows the effect of Business regulation on Social progress upon controlling for Basic needs. Based on the estimated relationship, both the coefficient of Business regulation $(\beta=0.172, p<.05)$ and that of Basic needs $(\beta=0.703, p<.05)$ are positive and highly statistically significant. However, the effect of Business regulation $(\beta=0.172)$ upon controlling for Basic needs is lower compared to the initial coefficient of Business regulation $(\beta=0.683)$. In the third model, the study controls for both Basic needs and personal Wellbeing. The estimated results indicate that the coefficients of Regulation $(\beta=0.0129, p<.05)$, Basic needs $(\beta=0.184, p<.05)$ and Wellbeing $(\beta=0.725, p<.05)$ are all positive and highly statistically significant in determining Social progress. The fourth model controls for Basic needs, personal Wellbeing, and Opportunity. Similarly, the estimated results indicate that the coefficient of Regulation $(\beta=0.0242, p<.05)$, Basic needs $(\beta=0.135, p<.05)$, Wellbeing $(\beta=0.636, p<.05)$, and Opportunity $(\beta=0.191, p<.05)$ are all positive and highly statistically significant in 
determining Social progress. The fifth model on the other hand controls for Basic needs, personal Wellbeing, Opportunity, and Nutrition. Based on the tabulated results, the coefficient of Regulation $(\beta=0.0167, p<.05)$, Basic needs $(\beta=$ $0.0304, p<.05)$, Wellbeing $(\beta=0.608, p<.05)$, Opportunity $(\beta=0.218, p<.05)$, and Nutrition $(\beta=0.132, p<$ $.05)$, are all positive and statistically significant in determining Social progress.

\section{Table 7}

Regression Estimates for the Relationship between Business Regulation and Social Progress

\begin{tabular}{|c|c|c|c|c|c|c|}
\hline Model & Model 1 & Model 2 & Model 3 & Model 4 & Model 5 & Model 6 \\
\hline Variables & Social progress & Social progress & Social progress & Social progress & Social progress & Social progress \\
\hline Regulation & $\begin{array}{l}0.683 * * * \\
(0.0392)\end{array}$ & $\begin{array}{l}0.172 * * * \\
(0.0218)\end{array}$ & $\begin{array}{l}0.0129 \\
(0.0100)\end{array}$ & $\begin{array}{l}0.0242 * * \\
(0.00788)\end{array}$ & $\begin{array}{l}0.0167^{*} \\
(0.00759)\end{array}$ & $\begin{array}{l}0.0137^{*} \\
(0.00725)\end{array}$ \\
\hline Basic & & $\begin{array}{l}0.703 * * * \\
(0.0140)\end{array}$ & $\begin{array}{l}0.184 * * * \\
(0.0105)\end{array}$ & $\begin{array}{l}0.135 * * * \\
(0.00954)\end{array}$ & $\begin{array}{l}0.0304 * \\
(0.0148)\end{array}$ & $\begin{array}{l}-0.0340 * \\
(0.0155)\end{array}$ \\
\hline Wellbeing & & & $\begin{array}{l}0.725 * * * \\
(0.0122)\end{array}$ & $\begin{array}{l}0.636 * * * \\
(0.0108)\end{array}$ & $\begin{array}{l}0.608 * * * \\
(0.0110)\end{array}$ & $\begin{array}{l}0.601 * * * \\
(0.0106)\end{array}$ \\
\hline Opportunity & & & & $\begin{array}{l}0.191 * * * \\
(0.00812)\end{array}$ & $\begin{array}{l}0.218^{* * *} * \\
(0.00850)\end{array}$ & $\begin{array}{l}0.193 * * * \\
(0.00853)\end{array}$ \\
\hline Nutrition & & & & & $\begin{array}{l}0.132 * * * \\
(0.0152)\end{array}$ & $\begin{array}{l}0.184 * * * \\
(0.0157)\end{array}$ \\
\hline Safety & & & & & & $\begin{array}{l}0.0700 * * * \\
(0.00774)\end{array}$ \\
\hline Constant & $\begin{array}{l}22.60 * * \\
(2.501)\end{array}$ & $\begin{array}{l}2.475 \\
(1.316)\end{array}$ & $\begin{array}{l}1.547^{*} \\
(0.654)\end{array}$ & $\begin{array}{l}0.503 \\
(0.373)\end{array}$ & $\begin{array}{l}-1.755 * * * \\
(0.450)\end{array}$ & $\begin{array}{l}-3.782 * * * \\
(0.493)\end{array}$ \\
\hline $\mathrm{N}$ & 782 & 782 & 782 & 782 & 782 & 782 \\
\hline
\end{tabular}

Standard errors in parentheses $=" * \mathrm{p}<0.05 \quad * * \mathrm{p}<0.01 * * * \mathrm{p}<0.001 "$

Lastly, model six controls for Basic needs, personal Wellbeing, Opportunity, Nutrition, and Safety. In this case, the study established that the coefficients of Regulation $(\beta=0.0137, p<.05)$, Basic needs $(\beta=-0.0304, p<.05)$, Wellbeing $(\beta=$ $0.601, p<.05)$, Opportunity $(\beta=0.193, p<.05)$, Nutrition $(\beta=0.184, p<.05)$, and Safety $(\beta=0.0700, p<.05$ are all statistically significant in determining Social progress. With the exception of Basic needs, all the other control variables had a positive effect on Social progress. Overall, the estimated results indicate that Business regulation has a positive and statistically significant effect on Social progress as given across all the six models that were estimated in this study. However, the overall effect of Business regulation, as given by the estimated regression coefficients under the respective models, kept varying with the introduction of an additional control variable. Intuitively, the results are an indication that Social progress is robust to the inclusion of the five control variables which in this case were; Basic needs, Wellbeing, Opportunity, Nutrition, and Safety. Moreover, all the five control variables have a statistically significant effect on Social progress.

\section{Post estimation diagnostic tests}

Further diagnostics were conducted to ascertain that the model satisfied the regression assumption of no serial correlation, and hence, determine that the resultant findings were valid.

\section{Testing for cross-sectional independence}

In this study, the Pasaran test of cross-sectional dependence was used to test for cross-sectional dependence. The null and alternative hypotheses were stated as;

H0: No serial correlation

HA: There is serial correlation

Table 7

Pasaran CD test of cross-sectional dependence

\begin{tabular}{lr} 
Pesaran's test of cross-sectional dependence $=0.562$, & $\mathrm{pr}=0.293$ \\
Average absolute value of the off-diagonal elements $=0.315$ & \\
\hline
\end{tabular}

The test results presented in Table 5 indicate that the coefficient of the test statistic $\mathrm{P}(0.562, \mathrm{p}>.293)$ is not statistically significant to reject the null hypothesis of no serial correlation. Instead, the decision that we fail to reject the null hypothesis and conclude that the model is not suffering from serial correlation. This therefore is an indication that the model was suitable for analyzing the effect of business regulations on social progress.

\section{Discussion and Conclusion}

This study examined the effect of business regulation of social progress. In order to achieve this objective, the study conducted the Hausman test on a data obtained from a sample of 782 countries where it was established that the random effect model was more appropriate for analysis as compared to the fixed effect model. Results of the random effect model indicated that business regulation consistently affected social progress before and after inclusion of different control variables into the regression model, although the magnitude of the effect kept varying with the introduction of an additional control variable. 
These findings are in accordance with the study expectations that business regulation significantly affects social progress. For instance, regulations on credit markets, investor rights and protection influence social progress through economic growth and the overall quality of life. On the other hand, credit markets affect the amount of money in circulation, while credit reporting systems agitate for information symmetry in the financial markets. The study findings are also in accordance with the findings of Giannetti and Jentzsch (2013) who had also established that compulsory credit reporting enhances financial accessibility and intermediation primarily when used alongside other information system. Similarly, Gine and Love (2009) found a positive relationship between improved regulations and social development by affecting economic performance. The implication of these findings is that, in order for governments to meaningfully improve the living standards of their citizens, it is high time that they devoted their resources to addressing the social indicators of progress as opposed to solely emphasizing on economic and environmental factors.

\section{Limitations of the study}

The scope of the current study was limited to determining the effect of business regulation on social progress. In this case, social progress was measured in terms of the social progress index of all the 782 countries that were under investigation as a single unit. The study therefore did not cluster the countries according to their prevailing level of income. Considering that the sampled countries are at different levels of development, and hence, income levels, it is possible that the study findings could be influenced by extreme values and may therefore not be used to draw general conclusions on the effect of business regulations. In view of this limitation, there is need for future studies to replicate the current study with the aim of determining the effect of business regulation on social progress in low-income, middle-income, and high-income countries. Through such, it will be possible to compare findings from countries at different levels of development, thus much able to draw binding conclusions on the effect of business regulation on social progress. Additionally, future studies may also want to examine the mediating role of the quality of organizational leadership in the relationship between business regulation and social progress.

\section{References}

Almatarneh, N., \& Emeagwali, O. L. (2019). Does institutional quality matter in fostering social progress: A cross national examination. Management Science Letters, 9(7), 1037-1046. https://doi.org/10.5267/j.msl.2019.4.002

Bečić, E., Mulej, E. M., \& Švarc, J. (2012). Measuring social progress by sustainable development indicators: Cases of Croatia and Slovenia. Procedia - Social and Behavioral Sciences, 37, 458465. https://doi.org/10.1016/j.sbspro.2012.03.311

Bruno, B., \& Faggini, M. (2017). Education, R\&D, and social progress. Eurasian Economic Review, 7(1), 3348. https://doi.org/10.1007/s40822-016-0062-9

Deloitte, \& Social Progress Imperative. (2015). Foreign direct investment and inclusive growth. The impacts on social progress. http://www2.deloitte.com/global/en/pages/about-deloitte/articles/fdi-and-inclusive-growth.html

Divanbeigi, R., \& Ramalho, R. (2015). Business regulations and growth. The World Bank.

Giannetti, C., \& Jentzsch, N. (2013). Credit reporting, financial intermediation and identification systems: International evidence. Journal of International Money and Finance, 33, 60-80. https://doi.org/10.1016/j.jimonfin.2012.10.005

Gine, X., \& Love, I. (2009). Evaluating the efficiency of a bankruptcy reform (54003). World Bank. https://openknowledge.worldbank.org/bitstream/handle/10986/10253/540030BRI0Impa1Box345635B001PUBLIC1.pdf?sequence=1

Hoekman, B., \& Nicita, A. (2011). Trade policy, trade costs, and developing country trade. World Development, 39(12), 2069-2079. https://doi.org/10.1016/j.worlddev.2011.05.013

IFC. (2013). IFC jobs study. Assessing private sector contributions to job creation and poverty reduction. https://www.ifc.org/wps/wcm/connect/a93ef4fe-8102-4fc2-8527-5aff9af7f74f/ifc_full+job+study+report_jan2013_final.pdf?mod=ajperes\&cvid=jmrye5j

Messaoud, B., \& Teheni, Z. E. (2014). Business regulations and economic growth: What can be explained? International Strategic Management Review, 2(2), 69-78. https://doi.org/10.1016/j.ism.2014.03.001

Social Progress Imperative. (2015). Social progress in 2030. Developing beyond economic growth. Deloitte. https://www2.deloitte.com/content/dam/Deloitte/sg/Documents/about-deloitte/sea-about-socialprogress-in-2030-report-noexp.pdf

Sumkoski, G. (2016). Towards socio-economic theory and practice of regulation. Evidence from OECD countries and Bangladesh. Cogent Social Sciences, 2(1), 1-22. https://doi.org/10.1080/23311886.2016.1254840

World Bank. (2013). Doing business 2014: Understanding regulations for small and medium-size enterprises. World Bank Publications.

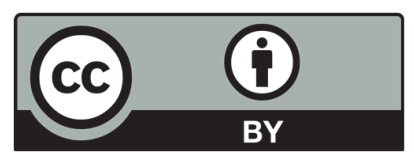

(C) 2021 by the authors; licensee Growing Science, Canada. This is an open access article distributed under the terms and conditions of the Creative Commons Attribution (CC-BY) license (http://creativecommons.org/licenses/by/4.0/). 